\title{
CURRENT STATUS OF GERMLINE STEM CELLS IN ADULT MAMMALIAN OVARY
}

\author{
Enes TAYLAN ${ }^{1,2 *}$, Yodo SUGISHITA ${ }^{3,4}$, Kenan KIRTEKE $^{5}$ \\ ${ }^{1}$ Samuel Oschin Comprehensive Cancer Institute, Cedars-Sinai Medical Center, Los Angeles, CA, USA \\ ${ }^{2}$ Laboratory of Molecular Reproduction and Fertility Preservation, Department of Obstetrics, Gynecology \& \\ Reproductive Sciences, Yale University School of Medicine, New Haven, CT, USA \\ ${ }^{3}$ Department of Obstetrics and Gynecology, St. Marianna University School of Medicine, Kawasaki, JAPAN \\ ${ }^{4}$ Department of Frontier Medicine, Institute of Medical Science, St. Marianna University, School of Medicine. Kawasaki, \\ JAPAN \\ ${ }^{5}$ Department of Obstetrics and Gynecology, Adnan Menderes University School of Medicine, Aydın, TURKEY \\ *Corresponding author: ORCID ID: orcid.org/0000-0002-0445-1250, e-mail: enes.taylan@cshs.org
}

\section{Cite this article as:}

Taylan E., Sugishita Y., Kirteke K. 2019. Current Status of Germline Stem Cells in Adult Mammalian Ovary. Trakya Univ J Nat Sci, 20(Special Issue): S63-S66, DOI: $10.23902 /$ trkjnat. 483495

Received: 15 November 2018, Accepted: 22 January 2019, Published: 1 February 2019

\begin{abstract}
The evolutionary and biological mechanisms underlying female reproductive aging have long been a matter of interest. Reproductive biologists have tackled with the relatively limited fertile period in female lifespan compared to male fertility that continues until the late ages. For more than five decades, it has been believed that females are born with a fixed number of germ cells that constitute ovarian follicle reserve and depletion of this reserve causes menopause. However, researchers recently reported findings that support the presence of oogenesis in postnatal mammalian ovaries, which caused a paradigm shift in our current knowledge of reproductive biology. In this minireview, we provide a brief history of one of the central dogmas in reproductive biology and subsequently present recent studies on the existence of germline stem cells in the mammalian ovary.
\end{abstract}

Key words: Ovary, stem cells, female germline, fertility preservation.

Özet: Dişi üreme sistemi yaşlanmasının altında yatan evrimsel ve biyolojik mekanizmalar uzun süredir ilgi çeken bir konu olmuştur. Üreme biyolojisi konusunda çalışan biyologlar, erkeklerde ileri yaşlara kadar devam eden fertilite ile karşılaştırıldığında dişi yaşamında görece olarak sınırlı bir dönemde görülen fertilite konusunu aydınlığa kavuşturmaya çalışmaktadırlar. 50 yılı aşkın bir süredir dişilerin ovaryan folikül rezervini oluşturan sabit sayıda germ hücresi ile dünyaya geldiklerine inanılmaktadır. Ancak, son dönemde araștırıcılar memeli ovaryumlarında doğum sonrası oogenez varlı̆̆ını destekleyen ve üreme biyolojisi ile ilgili günümüz bilgilerimizde değişime yol açan bulgular elde etmişlerdir. Bu derleme çalışmasında, üreme biyolojisindeki santral dogmalardan bir tanesi ile ilgili kısa bir tarihsel bilgi verilmiş ve memeli ovaryumlarında germ hattı kök hücrelerinin varlı̆̆ ile ilgili son dönem çalışmaları sunulmuştur.

\section{Introduction}

Adult stem cells or somatic stem cells with the ability to differentiate into certain mature cell types and regenerate the hosting tissue have been identified in several organs including brain, bone marrow, skeletal muscle, blood vessels, gut, and liver in the human body (Turksen 2014). These cells generally reside inactive for long periods in the tissues until they are needed to produce new cells to maintain tissue function and health.

The idea of the existence of stem cells that can produce mature oocytes in adult ovaries has been a debated concept with several supporting and against evidence. In the male reproductive system, testis hosts germline stem cells that continuously produce sperm cells throughout the reproductive lifespan until the late ages (Brinster 2007). On the other hand, in the female reproductive system, ovaries are known to be constituted with a limited number of primordial germ cells which is referred to as ovarian follicle reserve. During embryologic development, mitotically active oogonial cells rapidly proliferate and colonize the ovary with an approximate population of one million primordial germ cells at birth. This ovarian reserve gradually declines with age due to follicle apoptosis and reduces to $\sim 25.000$ primordial follicles by the age of 37 years. In the following years, follicle apoptosis accelerates and almost exhausts at the age of 51 years leading to the cessation of the menstrual cycle and menopause (Broekmans et al. 2009). 
For several decades, it has been a dogma in reproductive biology that females are born with a limited pool of oocytes that maintains reproductive capacity until the time of menopause. However, this dogma of unrenewable ovarian follicle reserve has been recently challenged by several studies suggesting the existence of germline cells with stem cell capabilities in the adult ovaries. In this review, we summarize our current knowledge and understanding of ovarian germline stem cells or oogonial stem cells under the light of evidence supporting and against the case.

\section{Stem Cells in Adult Mammalian Ovary}

The debate on follicle reserve in human ovary goes back to the $19^{\text {th }}$ century when Waldeyer $(1870)$ stated that oocyte production ceases at or shortly after birth. Waldeyer's statement was fundamentally based on the results from the studies conducted on ovaries from various mammalian species including dogs and cats. This statement was later supported by Pearl \& Schoppe (1921) and finally by Zuckerman's report in 1951, which lead to the conclusion that there was no evidence of postnatal oogenesis in human ovaries. Their conclusion generated a wide acceptance among reproductive scientists and rapidly became a central doctrine in the field of female reproductive biology. Though, during the following period, a few number of studies by Ioannou et al. (1967) and David et al. (1974) reported the potential presence of stem cells in the postnatal ovaries of primates. In these studies, researchers investigated the presence of oogonia undergoing cell division and found oocytes at various stages of meiosis. Based on the results, they concluded that oogenesis occurs in postnatal ovary. However, their findings were mainly limited to histological evaluation of the tissue sections without any specific markers for oocytes. Despite these early reports, the dogma has remained unchallenged for more than fifty years until recently by the works of Tilly's group from Harvard Medical School (Johnson et al. 2004).

In 2004, Tilly's group published a landmark paper claiming the existence of germline stem cells with the ability to produce oogonia and renew follicle pool in postnatal mammalian ovaries (Johnson et al. 2004). In their study, researchers initially investigated the follicle dynamics in C57BL/6 mice ovary. By demonstrating the discrepancy between the high follicle atresia rates and the number of follicles observed in the ovary throughout the reproductive period, the authors emphasized that the ovarian reserve would deplete by the young adulthood unless the follicle pool were replenished by an oocyte source, most likely by germline stem cells. To confirm that their findings were not related to the mice strain, they repeated the same experimental design in other mice strains as well including CD1 and AKR/J and reported similar findings. Subsequently, they showed the presence of proliferating germ cells histologically using doubleimmunostaining for a germ cell marker (MVH) and a proliferation marker (5-bromodeoxyuridine). To show the presence of meiotically active germ cells, researchers investigated synaptonemal complex protein 3 (SCP3), a meiosis-specific protein needed for the formation of axial, lateral elements of the synaptonemal complex, together with Spoll and Dmcl expressions in juvenile and young adult mouse ovaries. They reported an expression level of $6-25 \%$ compared to the expression in testis, which was significant. As a next step, researchers depleted specifically the germline cells using busulphan and examined the change in the follicle reserve. They found that despite the elimination of non-meiotic germline cells, the follicle reserve was stable over time suggesting its renewal by stem cells. In their final set of experiments, they grafted wild-type mouse ovary to transgenic GFPpositive mouse ovarian bursa, and they were able to observe GFP positive oocytes 3-4 weeks later in the grafted ovarian tissue concluding that oogenesis continues in postnatal ovary.

After publication of this landmark paper, a heated debate ignited in the field of reproductive biology followed by studies supporting the presence of oogonial stem cells (Bukovsky et al. 2005, Johnson et al. 2005, Abban \& Johnson 2009, Niikura et al. 2009, Zou et al. 2009, Pacchiarotti et al. 2010, Parte et al. 2011, White et al. 2012, Zhou et al. 2014) while others were refuting the findings of Tilly's group (Bristol-Gould et al. 2006, Liu et al. 2007, Kerr et al. 2012, Zhang et al. 2012, Zhang et al. 2014, Zarate-Garcia et al. 2016). The arguments against the ovarian germline stem cells include several points. First of all, it is emphasized that even if oogonial stem cells exist in the mouse ovary, it does not indicate the presence of neo-oogenesis in human ovary due to biological differences in two different mammalian species. Secondly, the cellular markers used by the researchers to identify oogonial stem cells are not specific to the germline. Therefore, it is criticized that the identified cells could not be accurately classified as germline stem cells. For example, Johnson et al. (2004) used MVH, also known as Ddx4, as a germline marker in their studies. However, researchers later on demonstrated MVH/Ddx4 expression in brain and kidney tissues in mice suggesting that MVH/Ddx4 cannot be used as a specific marker for germline cells (Liu et al. 2007, ZarateGarcia et al. 2016). Liu et al. (2007) also reported a lack of expression of meiotic marker Scp3 in their study. In a recent study, using a transgenic mice model genetically targeting another germline-specific marker, stimulated by retinoic acid gene 8 (Stra8), Wang et al. (2017) demonstrated oocyte generation in adult mice after targeted ablation of premeiotic germ cells.

Irrespective of these supporting and against reports, it is acknowledged that the lack of detection of proliferative and meiotic markers in the ovarian tissue samples cannot disprove the existence of the oogonial stem cells as these cells may remain quiescent without showing any significant activity. To investigate whether quiescent oogonial stem cells exist, Zhang et al. (2014) specifically ablated growing follicles in a transgenic mice model and examined whether quiescent stem cells would activate to 
replenish diminished reserve. Evaluations at 2, 6 and 12 months after follicle ablation showed no oocytes in mice ovaries suggesting the non-existence of quiescent germline stem cells. However, these findings were also objected as the factors which can activate germline stem cells might be different, and depletion of follicle reserve might not be adequate to induce activation.

Another issue with the identification of these stem cells is related to their unknown location such as ovarian cortex, surface epithelium or ovarian medulla. Hence, it is possible that studies focused on certain parts of the ovary might have overlooked these cells to detect. Additionally, in vitro culture conditions for studying oogonial stem cells can be unreliable to represent physiological conditions of the ovarian cellular microenvironment. Besides, culture conditions may fail to replicate hormonal and paracrine signaling conditions that exist in vivo. Therefore, identification and culture of oogonial stem cells possess many challenges for in vitro studies.

\section{Ovarian Stem Cells of Extragonadal Origin}

Some researchers alternatively proposed that the stem cells identified in the ovaries may have been originated from other organs and later migrated to the ovary. Lee et al. (2007) and Selesniemi et al. (2009) reported that bonemarrow derived stem cells migrate to ovaries after bonemarrow transplantation and contribute oogenesis. On the other hand, in a parabiosis model with GFP positive mice, Eggan et al. (2006) demonstrated that there was no evidence of circulating cells contributing to ovulated oocytes. Therefore, it is still unclear whether bonemarrow derived stem cells take a role in oogenesis and their primary function in ovarian biology needs to be further investigated. It is a possibility that migrated extragonadal stem cells to the ovary can enhance folliculogenesis by primarily supporting the ovarian microenvironment.

\section{Ovarian Stem Cells and Reproductive Aging}

One of the critical questions regarding the existence of ovarian germline stem cells is that if this previously unknown source could replenish follicle reserve, then why women go through menopause? Researchers have proposed different answers to this question. One of the most accepted explanations is that stem cell functions would also decline by aging as seen in male germline leading to loss of renewal potential (Ermolaeva et al. 2018). Another possible explanation is that although oogonial stem cells maintain their differentiation into

\section{References}

1. Abban, G. \& Johnson, J. 2009. Stem cell support of oogenesis in the human. Human Reproduction, 24(12): 2974-2978.

2. Brinster, R.L. 2007. Male germline stem cells: from mice to men. Science, 316(5823): 404-405.

3. Bristol-Gould, S.K., Kreeger, P.K., Selkirk, C.G., Kilen, S.M., Mayo, K.E., Shea, LD. \& Woodruff, T.K. 2006. Fate of the initial follicle pool: empirical and mathematical oocytes, the functional deterioration of supporting follicular cells such as granulosa and theca cells may result in loss of follicle reserve. In another theory, researchers proposed that systemic age-related signals may cause ovarian function decline despite the presence of oogonial stem cells (Niikura et al. 2009).

\section{Potential Applications of Ovarian Stem Cells}

Although the existence of oogonial stem cells is still not conclusively proven, it has the great potential to revolutionize reproductive medicine and transform current treatment options for female infertility and gonadal endocrine insufficiency (Truman et al. 2017). Infertility and ovarian failure due to gonadotoxic treatments such as chemotherapy and radiation therapy have become important issues with an increasing rate in the modern age. In the last two decades, various assisted reproductive technologies and fertility preservation methods including ovarian tissue cryopreservation and transplantation procedures have been developed and successfully introduced to the clinical practice (Oktay et al. 2017, Taylan \& Oktay 2017, Taylan \& Oktay 2019). However, these available options also have certain limitations that restrict their application to all patients. Therefore, ovarian germline stem cells hold the potential to provide treatment with a wide range of application in reproduction and endocrine function maintenance.

\section{Conclusion}

Based on our current knowledge, there is an accumulating data supporting the potential existence of postnatal oogenesis in the adult mammalian ovary. However, there are still several limitations particularly in the identification of the ovarian germline stem cells which require markers specific to the oogonial stem cells. Another technical limitation is obtaining human ovarian tissue samples preferably from reproductive age women for stem cell research. Although experimental animal studies in mammalian species can demonstrate the presence of oogonial stem cells, this cannot lead to the same conclusion unless these stem cells are clearly shown in the human ovary. Therefore, studies in human ovarian samples have critical value. Despite these limitations, there have been significant advances in molecular biology and reproductive medicine, and these developments will most likely lead us to a conclusive answer in the search of stem cells in the human ovary and may provide novel treatment options for female infertility and menopauserelated health conditions.

evidence supporting its sufficiency for adult fertility. Developmental Biology, 298(1): 149-154.

4. Broekmans, F.J., Soules, MR. \& Fauser, B.C. 2009. Ovarian Aging: Mechanisms and Clinical Consequences. Endocrine Reviews, 30(5): 465-493.

5. Bukovsky, A., Svetlikova, M. \& Caudle, M.R. 2005. Oogenesis in cultures derived from adult human ovaries. Reproductive Biology and Endocrinology, 3: 17. 
6. David, G.F., Anand-Kumar, T.C. \& Baker, T.C. 1974. Uptake of tritiated thymidine by primordial germ cells in the ovaries of adult slender loris. Journal of Reproduction and Fertility, 41: 447-451.

7. Eggan, K., Jurga, S., Gosden, R., Min, I.M. \& Wagers, A.J. 2006. Ovulated oocytes in adult mice derive from noncirculating germ cells. Nature, 441(7097): 1109-1114.

8. Ermolaeva, M., Neri, F., Ori, A. \& Rudolph, K.L. 2018. Cellular and epigenetic drivers of stem cell ageing. Nature Reviews Molecular Cellular Biology, 19(9): 594-610.

9. Ioannou, J.M. 1967. Oogenesis in adult prosimians. Journal of Embryology and Experimental Morphology, 17: 139-145.

10. Johnson, J., Canning, J., Kaneko, T., Pru, J.K. \& Tilly J.L. 2004. Germline stem cells and follicular renewal in the postnatal mammalian ovary. Nature, 428(6979): 145-150.

11. Johnson, J., Bagley, J., Skaznik-Wikiel, M., Lee, H.J., Adams, G.B., Niikura, Y., Tschudy, K.S., Tilly, J.C., Cortes, M.L., Forkert, R., Spitzer, T., Iacomini, J., Scadden, D.T. \& Tilly, J.L. 2005. Oocyte generation in adult mammalian ovaries by putative germ cells in bone marrow and peripheral blood. Cell, 122(2): 303-315.

12. Kerr, J.B., Brogan, L., Myers, M., Hutt, K.J., Mladenovska, T., Ricardo, S., Hamza, K., Scott, C.L., Strasser, A. \& Findlay, J.K. 2012. The primordial follicle reserve is not renewed after chemical or irradiation mediated depletion. Reproduction, 143(4): 469-476.

13. Lee, H.J., Selesniemi, K., Niikura, T., Klein, R., Dombkowski, D.M. \& Tilly, J.L. 2007. Bone marrow transplantation generates immature oocytes and rescues long-term fertility in a preclinical mouse model of chemotherapy-induced premature ovarian failure. Journal of Clinical Oncology, 25(22): 3198-3204.

14. Liu, Y., Wu, C., Lyu, Q., Yang, D., Albertini, D.F., Keefe, D.L. \& Liu, L. 2007. Germline stem cells and neooogenesis in the adult human ovary. Developmental Biology, 306(1): 112-120.

15. Niikura, Y., Niikura, T. \& Tilly, J.L. 2009. Aged mouse ovaries possess rare premeiotic germ cells that can generate oocytes following transplantation into a young host environment. Aging, 1(12): 971-978.

16. Oktay, K., Taylan, E., Sugishita, Y. \& Goldberg, G.M. 2017. Robot-assisted Laparoscopic Transplantation of Frozen-thawed Ovarian Tissue. Journal of Minimally Invasive Gynecology, 24(6): 897-898.

17. Pacchiarotti, J., Maki, C., Ramos, T., Marh, J., Howerton, K., Wong, J., Pham, J., Anorve, S., Chow, Y.C. \& Izadyar, F. 2010. Differentiation potential of germ line stem cells derived from the postnatal mouse ovary. Differentiation, 79(3): 159-170.

18. Parte, S., Bhartiya, D., Telang, J., Daithankar, V., Salvi, V., Zaveri, K. \& Hinduja, I. 2011. Detection, characterization, and spontaneous differentiation in vitro of very small embryonic-like putative stem cells in the adult mammalian ovary. Stem Cells and Development, 20(8): 1451-1464.
19. Pearl, R. \& Schoppe, WE. 1921. Studies on the physiology of reproduction in the domestic fowl. Journal of Experimental Zoology, 34(1): 100-118.

20. Selesniemi, K., Lee, H.J., Niikura, T. \& Tilly, J.L. 2009. Young adult donor bone marrow infusions into female mice postpone age-related reproductive failure and improve offspring survival. Aging, 1(1): 49-57.

21. Taylan, E. \& Oktay, K. 2019. Autologous Transplantation of Human Ovarian Tissue, 493-500. In: Peter CK Leung and Eli Y Adashi, The Ovary. $3^{\text {rd }}$ Edition, Elsevier. (https://doi.org/10.1016/B978-0-12-813209-8.00030-3)

22. Taylan, E. \& Oktay, K.H. 2017. Current state and controversies in fertility preservation with breast cancer. World Journal of Clinical Oncology, 8(3): 241-248.

23. Truman, A.M., Tilly, J.L. \& Woods, D.C. 2017. Ovarian regeneration: The potential for stem cell contribution in the postnatal ovary to sustain endocrine function. Molecular and Cellular Endocrinology, 445: 74-84.

24. Turksen, K. (Editor). 2014. Adult Stem Cells. Second Edition. Springer.

25. Waldeyer, W. 1870. Eirstock und Ei. Germany: Engelmann.

26. Wang, N., Satirapod, C., Ohguchi, Y., Park, E-S., Woods, D.C. \& Tilly, J.L. 2017. Genetic studies in mice directly link oocytes produced during adulthood to ovarian function and natural fertility. Scientific Reports, 7(1): 10011.

27. White, Y.A.R., Woods, D.C., Takai, Y., Ishihara, O., Seki, H. \& Tilly, J. 2012. Oocyte formation by mitotically active germ cells purified from ovaries of reproductive-age women. Nature Medicine, 18(3): 413-421.

28. Zarate-Garcia, L., Lane, S.I.R., Merriman, J.A. \& Jones, K.T. 2016. FACS-sorted putative oogonial stem cells from the ovary are neither DDX4-positive nor germ cells. Scientific Reports, 6: 27991.

29. Zhang, H., Liu, L., Li, X., Busayavalasa, K., Shen, Y., Hovatta, O., Gustafsson, J.A. \& Liu, K. 2014. Life-long in vivo cell-lineage tracing shows no oogenesis originates putative germline stem cells in adult mice. Proceedings of the National Academy of Sciences of the United States, 111(50): 17983-17988.

30. Zhang, H., Zheng, W., Shen, Y., Adhikari, D., Ueno, H. \& Liu, K. 2012. Experimental evidence showing that no mitotically active female germline progenitors exist in postnatal mouse ovaries. Proceedings of the National Academy of Sciences of the United States, 109(31): 1258012585.

31. Zhou, L., Wang, L., Kang, J.X., Xie, W., Li, X., Wu, C., $\mathrm{Xu}, \mathrm{B} . \& \mathrm{Wu}, \mathrm{J} .2014$. Production of fat- 1 transgenic rats using a postnatal female germline stem cell line. Molecular Human Reproduction, 20(3): 271-281.

32. Zou, K., Yuan, Z., Yang, Z., Luo, H., Sun, K., Zhou, L., Xiang, J., Shi, L., Yu, Q., Zhang, Y., Hou, R. \& Wu, J. 2009. Production of offspring from a germline stem cell line derived from neonatal ovaries. Nature Cell Biology, 11(5): 631-636. 